Vol. XVII No. 2

\title{
Parks and People
}

\section{By P. A. Gregg, Conservation Information Service, Department of Natural Resources.}

Why do Saskatchewan's provincial parks attract thousands of visitors each year? This seemingly simple question might be answered by enumerating specific activities such as swimming, fishing, or camping, but a better answer would be in terms of fundamental human needs.

All human beings require some form of recreation and a large percentage of them prefer outdoor recreation. The reasons for this preference are probably rooted in antiquity, for with the possible exception of the past hundred years or so, most people lived close to the land and were employed in agriculture or some other outdoor activity. All down through pre-history and historical times this has been man's role and he was well adapted to it. In the face of today's artificial environments and the tensions of the atomic age it is little wonder that people visit our parks. Consciously or unconsciously they are seeking renewed contact with nature and a refreshing relaxation from the high-pressure pattern of their lives.

Over the past decade or so an increasing number of Saskatchewan's people have actively taken part in sone form of outdoor recreation and the pressure of their numbers is being felt within our parks and outside them as well. Why has this upsurge in the use of parks and outdoor recreation in general come about? Aside from natural population growth, increased urbanization and the hectic pace of our industrially oriented life provide the answer. Paradoxically, these changes have furnished the public with not only the motivation but also with the means and the money to travel more extensively about our countryside and to visit more parks. The average person today enjoys more leisure time, a better car and a generally higher living standard than did the previous generation. Equally important, the quality and quantity of our roads are vastly improved. It is to be expected, therefore, that such an individual will visit more parks and visit parks more often.

But population growth, development and industrialization create two other conditions which compound the problems facing parks and people. In many instances, these economic forces stimulate city growth at geographical locations where there is

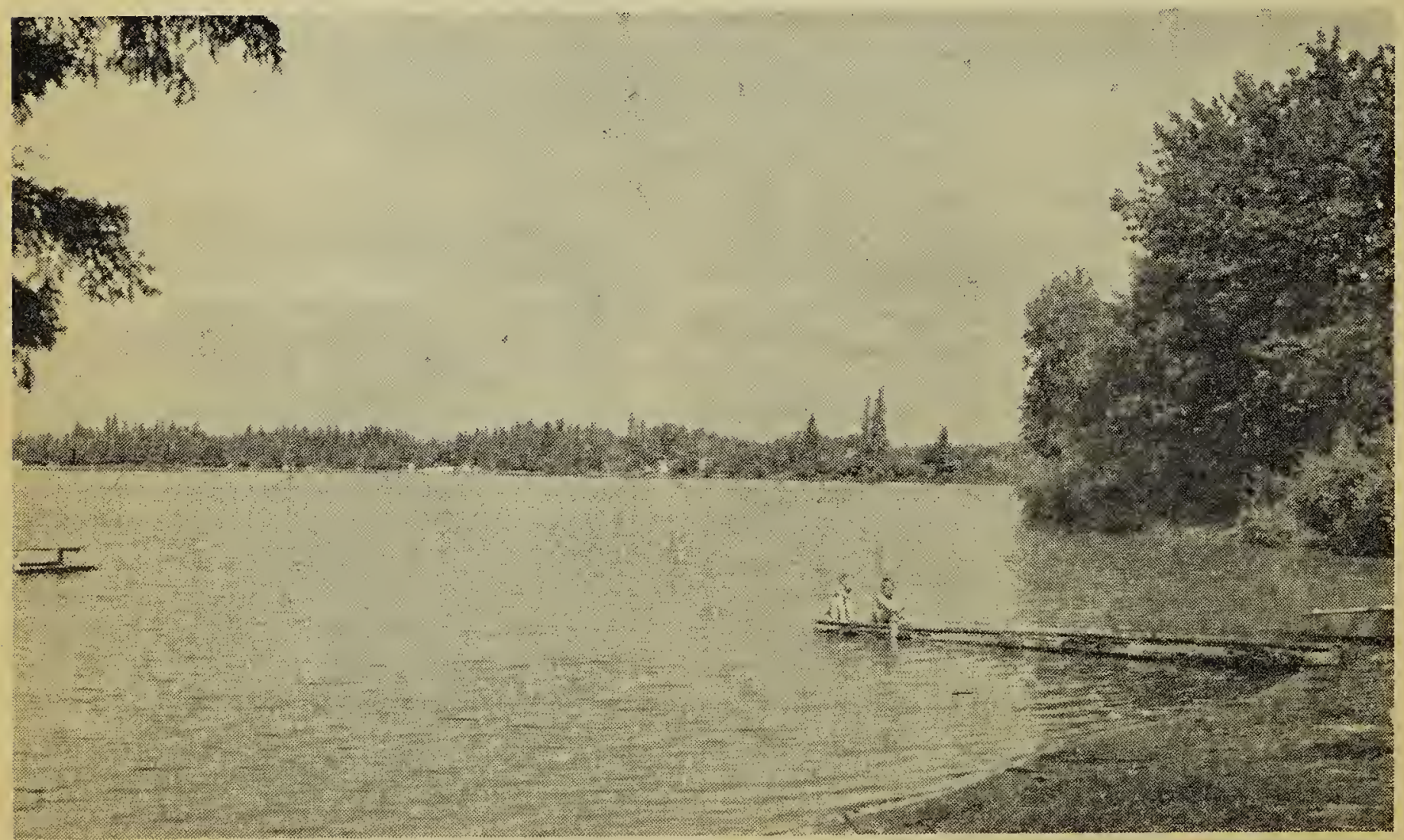


little or no naturally attractive area nearby which would be suitable for development into parks. Secondly urbanization tends to utilize for nonrecreational purposes areas near cities which may possess marginal recreational potential. This occurs because such locations are quickly taken up for industrial purposes, subjected to intensive agriculture or posted against trespassing by the owners who object to the public using them intensively for picnics, camping, etc.

The Utopian solution to the problem of what to do about large numbers of urban and rural people who want more outdoor recreation would be the creation of an adequate number of strategically located, scenically attractive provincial parks containing all the natural features and manmade facilities which would appeal to a wide variety of specific tastes. However, in southern Saskatchewan the population concentrations are situated at considerable distances from most provincial parks and the best recreational areas of the province.

The seriousness of this situation was recognized early by the provincial Department of Natural Resources. Because of the dearth of information on outdoor recreation in Saskatchewan and park needs, particularly in the southern part of the province, the Department of Natural Resources obtained the services of a qualified recreational consultant to conduct a recreational survey and make recommendations.

As a result of the survey and recommendations made by $W$. $M$. Baker, the Department of Natural Resources has attacked the problem by establishing three new provincial parks and expects to create more in the future, particularly in the southern part of the province where the need is already acute.

A great many factors must be evaluated before a new park is created. A careful investigation of the natural suitability of the area for use as a park is undertaken and top priority is given to such features as water, beaches, forest cover, and scenery. Because of the urgent need for park facilities in southern Sask. atchewan, accessibility from the major population areas and cities is

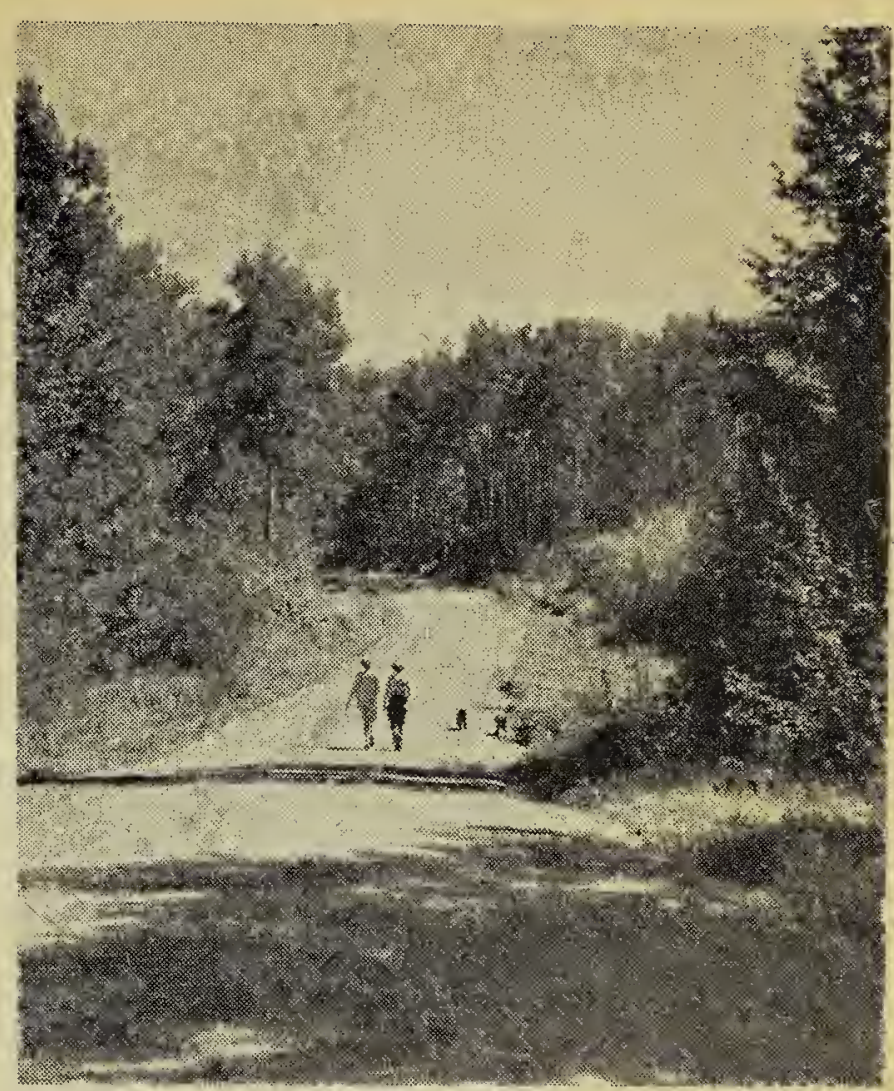

Sask. Govt. Photo.

OFF FOR A WALK: A view of one of the many tree-bondered roads at Duck Mountain Provincial Park.

an extremely important criterion in choosing an area for a park. This means that highly inaccessible areas possessing only marginal natural features must receive serious consideration as future parks to serve the needs of nearby population centres. Whatever natural features these key locations possess must be used as fully as possible. Because such areas do not, as a rule, contain all the desirable natural attributes of an ideal park, careful thought must be given to the feasibility of improving or creating artificially those features which they lack. Tree planting, fish stocking, water impoundment and beach construction are common exampleis of this type of improvement.

People visiting various provincial parks are impressed by the great difference in size and natural features which they observe. These variations arise in part from the natural differences in forest cover, topography and climate which occur at widely separated locations within the province. However, other differences among our parks can be attributed to the limitations imposed by the need for a high degree of accessibility to cities. Natural differences, plus those which are dictated by the need for accessibility, give rise to the various 
specialized types of parks which are found in Saskatchewan.

The first of these types of parks is the wilderness park which, as the name implies, contains a large tract of land generally far removed from population centres. In order to administer these areas and to provide the minimum accommodations essential for the park's use, a wilderness park may contain small developed nuclei. Because of its location and inherent qualities, a wilderness park is not used as intensively as some of the other types; however, the continued existence of wilderness parks can be fully justified for the enjoyment of those people who desire contact with unspoiled, wild beauty.

Compared with wilderness parks, multi-purpose parks are less extensive in size and located near population centres. In spite of the fact that they are much more intensively used and contain more cottage developments and other facilities, multi-purpose parks usually support plenty of big and small game. Some smaller multi-purpose parks become almost entirely regional in function and chiefly serve the recreational requirements of some nearby city.

The smallest types of parks are parkettes and roadside picnic sites. These not only provide pleasant and easily accessible locations for a family picnic but make a relatively low cost holiday trip possible for many families who would otherwise be forced to stop at expensive restaurants for meals.

Will the creation of more of these various types of parks tailored to meet the specific recreational needs of Saskatchewan's people, provide a solution to the mounting pressures for more park facilities? Only the future can answer this question with finality. But in the future lies great hope. The establishment and maintenance of more parks is a challenge which surely will be met. Equally, important, however, to the success of any program of park recreational development is the attitude of the people. Aldo Leopold, father of the modern wildlife conservation movement, has said:

"Recreation development is a job, not of building roads into lovely country, but of building receptivity

into the still unlovely human mind."
It is heartening to note that according to the Baker report the thing which pleased people most about our provincial parks was not the opportunities for quiet or rest, or even the pleasures of picnicking or fishing, but the park's beautiful scenery. Certainly there is no lack of receptivity here.

\section{ESTABLISHING A WILDLIFE SANCTUARY AT ROCANVILLE}

\section{By E. E. Symons, Rocanville}

Since last fall was an extremely dry season, it was possible for us to complete a project that we have had in mind for a long time. This project was the establishing of a wildlife sanctuary on a quarter section of wild Iand which I have owned for years, six miles north and two miles east of Wapella (or ten miles west and two miles south of Rocanville). This is a piece of land with many sloughs and deep "potholes," and stones galore. It was burned over in 1932 and left completely black, but it now has a 27-year growth of poplar and willow covering over $90 \%$ of the area.

Ten years ago we decided to turn this quarter section into a wildlife sanctuary. The first job was to build a dam on the road allowance, and we did this with the assistance of the municipality. The dam was fine until the water got high, when it simply overflowed at another place! Then the muskrats burrowed under the dam and water seeped through all summer, keeping our neighbour's property downstream sticky most of the season!

Last fall the sloughs were bone dry, and we felt that it was "now-ornever." Our plans at first were modest-we intended to have a big dugout excavated and some filling done. As the work progressed, however, we realized that this was the time to go ahead with our plans, even if they involved further expense. We ended up with a water conservation area which will cover from 12 to 15 acres at high-water level. We built levees where needed around the main pond, in which the water will reach a depth of four and one half feet at several points; we raised dams on the road 12 to 15 